\title{
Comments on "An error-correcting system for mobile radio data transmission"
}

\author{
Paaske, Erik
}

Published in:

I E E E Transactions on Vehicular Technology

Link to article, DOI:

10.1109/T-VT.1981.23878

Publication date:

1981

Document Version

Publisher's PDF, also known as Version of record

Link back to DTU Orbit

\section{Citation (APA):}

Paaske, E. (1981). Comments on "An error-correcting system for mobile radio data transmission". I E E E Transactions on Vehicular Technology, 30(1), 42-42. https://doi.org/10.1109/T-VT.1981.23878

\section{General rights}

Copyright and moral rights for the publications made accessible in the public portal are retained by the authors and/or other copyright owners and it is a condition of accessing publications that users recognise and abide by the legal requirements associated with these rights.

- Users may download and print one copy of any publication from the public portal for the purpose of private study or research.

- You may not further distribute the material or use it for any profit-making activity or commercial gain

- You may freely distribute the URL identifying the publication in the public portal

If you believe that this document breaches copyright please contact us providing details, and we will remove access to the work immediately and investigate your claim. 


\section{REFERENCES}

[1] G. R. Cooper and R. W. Nettleton, "A spread-spectrum technique for high-capacity mobile communications," IEEE Trans. Veh. Technol., vol. VT-27, pp. 264-275, Nov. 1978.

[2] M. Matsumoto and G. R. Cooper, "Narrowband interference in an FH-DPSK spread-spectrum communication system," in Conf. Rec. 1980 Nat. Telecommunications Conf., Dec. 1980.

[3] G. R. Cooper and R. W. Nettleton, "Spectral efficiency in cellular land-mobile communications: A spread-spectrum approach," TREE 78-44, Final Rep. on NSF Grant ENG 76-80536, Oct. 31, 1978.

[4] P. S. Henry, "Spectrum efficiency of a frequency-hopped-DPSK spread spectrum mobile radio system," IEEE Trans. Veh. Technol., vol. VT-28, Nov. 1979.

[5] A. Papoulis, Probability, Random Variables, and Stochastic Processes. New York: McGraw-Hill, 1965, pp. 132-134.

[6] Y. A. Shreider, The Monte Carlo Method, G. T. Tee, tr. New York: Perganon, 1966.

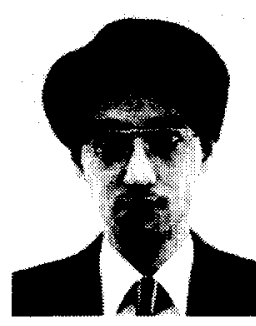

Masao Matsumoto was born in Nagasaki, Japan, on July 7,1951 . He received the B.S. degree and the M.S. degree from Kyoto University, Kyoto, Japan, in 1974 and 1976 , respectively.

Since 1976 he has been employed by the Radio Regulatory Bureau, the Ministry of Posts and Telecommunications, Tokyo, Japan. He is currently studying at Purdue University, West Lafayette, IN, on a fellowship of the Japan International Cooperation Agency (JICA).

George R. Cooper (A'44-M'44-F'69), for biography and photograph please see page 29 of this issue.

\section{Technical Correspondence}

\section{Comments on "An Error-Correcting System for Mobile Radio Data Transmission"}

ERIK PAASKE, MEMBER, IEEE

\begin{abstract}
It is pointed out that, except for some minor changes, the above paper ${ }^{1}$ is a true copy of an earlier correspondence by En, and that the code presented should not be recommended.
\end{abstract}

In the subject paper, ${ }^{1}$ En presents a "new" rate one-half convolutional code, and he also claims that his code is one of the most efficient two-bit error-correcting codes "known to the author." Except for some minor changes, this paper is a true copy of a correspondence by En in 1977 [1].

In [2] the author showed that the system proposed by En should not be recommended, since another system exists which is superior to the one proposed by En. The reply from En is found in [3].

\section{REFERENCES}

[1] J. En, "A new random-error-correction code," IEEE Trans. Comput., vol. C-26, pp. 86-88, Jan. 1977.

Manuscript received October 30, 1980.

The author is with the Institute of Circuit Theory and Telecommunication, Technical University of Denmark, Building 343, DK-2800 Lyngby, Denmark. Telephone 452881566 .

1 J. En, IEEE Trans. Veh. Technol., vol. VT-29, pp. 278-280, May 1980.
[2] E. Paaske, "Comments on 'A new random-error-correction code'," IEEE Trans. Comput., vol. C-28, pp. 255-257, Mar. 1979.

[3] J. En, "Author's reply," IEEE Trans. Comput., vol. C-28, pp. 257-258, Mar. 1979

\section{Correction to "Ignition Noise of Foreign and Domestic Vehicles in Use in the United States"}

\section{RICHARD A. SHEPHERD, MEMBER, IEEE}

In the above paper, ${ }^{1}$ the last paragraph on page 343 contains a sentence which reads:

"Individual vehicles do become suddenly noisy when their resistive ignition system cabling is replaced with nonresistive plugs."

The sentence should read:

"Individual vehicles do become suddenly noisy when their resistive ignition system cabling is replaced by solid metallic wiring or as resistive spark plugs are replaced with nonresistive plugs."

Manuscript received October 16, 1980.

1 R. A. Shepherd and J. C. Gaddie, IEEE Trans. Veh. Technol., vol. VT-29, pp. 338-345, Aug. 1980. 